\title{
Heat tolerance of Nelore, Senepol $x$ Nelore and Angus $x$ Nelore heifers in the southeast region of Brazil
}

\author{
A.R.B. Ribeiro ${ }^{1 \#}$, M.M. Alencar ${ }^{2}$, A.R. Freitas ${ }^{3}$, L.C.A. Regitano ${ }^{3}$, M.C.S. Oliveira $^{3}$ \\ and A.M.G. Ibelli ${ }^{4}$ \\ ${ }^{1}$ Post-doc, Southeast - Embrapa Cattle (CPPSE) - São Carlos, Brasil. Financial support: FAPESP \\ ${ }^{2}$ Researcher, Southeast - Embrapa Cattle (CPPSE) - São Carlos, Brasil. CNPq's researcher \\ ${ }^{3}$ Researcher, Southeast - Embrapa Cattle (CPPSE) - São Carlos, Brasil. \\ ${ }^{4}$ Graduate student, Federal University of São Carlos (UFSCAR) - São Carlos - Brasil
}

\begin{abstract}
The Brazilian beef industry has experienced an increase in the utilization of adapted and non-adapted Bos taurus breeds in crossbreeding systems. In spite of this, little is known about the adaptability of these groups and of their crossbred progeny when raised in a tropical climate. The aim of this study was to evaluate the physiological responses related to adaptability of Nelore (NE), crossbred Angus x Nelore (TA) and Senepol $x$ Nelore (SN) cattle submitted to a heat tolerance trial. The study was conducted in the Southeast - Embrapa Cattle (CPPSE), São Carlos, Brazil. During the summer of 2008, 45 heifers, 15 of each breed type, were evaluated over three days: at 7:00 a.m. (resting measure), at 13:00 (after six hours in the sun with no access to water and shade) and at 15:00 (after a further two hours in the sun with access to shade). Rectal temperature and sweating rate were measured and the data were analyzed using restricted maximum likelihood. The effect of breed type was significant for rectal temperature only at 15:00 and for the sweating rate at all three test periods. Based on these results, Senepol x Nelore heifers showed a better adaptation in the heat tolerance test than the other breed types.
\end{abstract}

Keywords: Thermoregulation, adaptation, sweating rate, heat stress

"Corresponding author. E-mail: andrearbr@yahoo.com.br

\section{Introduction}

The Brazilian beef industry plays an important role in the world market, representing the largest commercial beef herd with the second highest beef production in the world (FAS-USDA, 2008). Almost $90 \%$ of the beef cattle in Brazil have Bos indicus genotype what demonstrated the economic value placed on adaptability traits of these breeds in tropical regions. Despite these characteristics, they present some undesirable productive traits such as poor meat tenderness, carcass quality, fertility and temperament, which justify the growing interest among cattle producers of introducing alternative germ plasm, to be used in crossbreeding programmes that could improve meat quality as well as productivity of the herds without losing adaptability.

The aim of this study was to evaluate the physiological responses related to adaptability of Nelore (NE), and crossbred Angus x Nelore (TA) and Senepol x Nelore (SN) heifers, submitted to a heat tolerance test, during a summer season in the south-eastern region of Brazil.

\section{Materials and Methods}

The study was conducted at the experimental station of the Brazilian Agricultural Research Corporation (EMBRAPA), Southeast-Embrapa Cattle (CPPSE), localized in São Carlos ( $21^{\circ} 5^{\prime}$ 'S and $\left.47^{\circ} 48^{\prime} \mathrm{W}\right)$, State of São Paulo, in the south-eastern region of Brazil. The environment is classified as subtropical with dry winters and hot/humid summers. A total of 45 heifers, 15 Angus $x$ Nelore (AN), 15 Senepol x Nelore (SN) and 15 Nelore (NE), approximately 14 months of age, were evaluated in a heat tolerance test during the summer season of 2007/2008 (December, 2007 and January and February, 2008).

In order to make handling procedures feasible, the 45 animals were separated into three groups of 15 animals (handling groups- HG), with five animals of each breed type in each group. In these three handling groups three repeated measures were recorded on each animal during three hot, sunny days, totalling a nine day trial. Rectal temperature and sweating rate of each animal were measured and meteorological data (air 
temperature, relative humidity and black globe temperature) were recorded every two hours, and were used to estimate a Temperature-Humidity Index (THI) (Thom, 1958) and Black Globe Humidity-Index (BGHI) (Buffington et al., 1981).

A day before each test, the animals were taken to a pasture adjacent to the corral with free access to water and shade. At approximately 6:00 animals were calmly moved to the corral where they rested for one hour. At 7:00 the animals were taken to the squeeze chute for the first series of measurements (M1). The animals were then kept in the corral with no access to water or shade until 13:00 when the second series of measurements (M2) was recorded. Thereafter, the animals were kept for one more hour in the corral with access only to shade but not water, and then the third series of measurements (M3) were taken at 15:00.

Rectal temperature and sweating rate data were analyzed as repeated measures by restricted maximum likelihood using the MIXED procedures of SAS (SAS, 2002-2003) considering a model that besides the overall mean included the effects of breed type (BT), handling group (HG), BT x HG, animal within BT $\mathrm{x}$ HG, measurement (MED - three repeated measures on each animal), BT x MED and HM x MED.

\section{Results and Discussion}

During the experimental period the values of air temperature, black globe temperature and relative humidity measurements varied between $17{ }^{\circ} \mathrm{C}$ and $38{ }^{\circ} \mathrm{C}, 16^{\circ} \mathrm{C}$ and $39^{\circ} \mathrm{C}$ and $50 \%$ and $95 \%$, respectively. According to Hahn \& Mader (1997) beef cattle can be severely affected in environments with THI values of above 79. The THI in the present study varied between 62.1 and 84 and the BGHI from 60.7 to 91.2.

Table 1 Least square means ( \pm standard error) of rectal temperature $\left({ }^{\circ} \mathrm{C}\right)$ measured at 7:00 (RT7), 13:00 (RT13) and 15:00 (RT15), during the heat tolerance test on Nelore, Senepol x Nelore and Angus x Nelore groups

\begin{tabular}{lccc}
\hline Breed type & RT7 $\left({ }^{\circ} \mathrm{C}\right)$ & RT13 $\left({ }^{\circ} \mathrm{C}\right)$ & RT15 $\left({ }^{\circ} \mathrm{C}\right)$ \\
\hline Nelore (NE) & $39.8 \pm 0.08$ & $40.0 \pm 0.04$ & $40.2^{\mathrm{a}} \pm 0.04$ \\
Senepol x Nelore (SN) & $39.5 \pm 0.08$ & $39.8 \pm 0.04$ & $39.8^{\mathrm{b}} \pm 0.04$ \\
Angus x Nelore (AN) & $39.5 \pm 0.08$ & $39.9 \pm 0.04$ & $40.0^{\mathrm{c}} \pm 0.04$
\end{tabular}

a,b,c $(\mathrm{P}<0.05)$ by Tukey test.

RT7, RT13 and RT15 - rectal temperatures measured at 7:00 am, 13:00 and at 15:00, respectively.

Table 2 Least square means ( \pm standard error) of sweating rate $\left(\mathrm{g} / \mathrm{m}^{2} / \mathrm{h}\right.$ ) measured at 7:00 a.m. (SR7), 13:00 (SR13) and 15:00 (SR15), during the heat tolerance test on the Nelore, Senepol x Nelore and Angus x Nelore groups

\begin{tabular}{lccc}
\hline Breed type & $\mathrm{SR} 7\left(\mathrm{~g} / \mathrm{m}^{2} / \mathrm{h}\right)$ & $\mathrm{SR} 13\left(\mathrm{~g} / \mathrm{m}^{2} / \mathrm{h}\right)$ & $\mathrm{SR} 15\left(\mathrm{~g} / \mathrm{m}^{2} / \mathrm{h}\right)$ \\
\hline Nelore (NE) & & & \\
Senepol x Nelore (SN) & $494.1^{\mathrm{a}} \pm 9.71$ & $579.9^{\mathrm{a}} \pm 10.01$ & $689.5^{\mathrm{a}} \pm 10.93$ \\
Angus x Nelore (AN) & $389.0^{\mathrm{b}} \pm 8.50$ & $437.9^{\mathrm{b}} \pm 10.01$ & $475.2^{\mathrm{b}} \pm 11.42$ \\
& $484.9^{\mathrm{a}} \pm 8.72$ & $602.1^{\mathrm{a}} \pm 9.92$ & $672.6^{\mathrm{a}} \pm 11.41$ \\
\hline
\end{tabular}

\footnotetext{
a,b $(\mathrm{P}<0.05)$ by Tukey test.

SR7, SR13 and SR15 - sweating rate measured at 7:00 am, 13:00 and at 15:00, respectively.
}

In the study the effect of breed type on rectal temperature was significant $(\mathrm{P}<0.05)$ only at the third measurement (M3) at 15:00, and for sweating rate at all three measurements $(\mathrm{P}<0.01)$. The Senepol $x$ Nelore group had the lowest mean rectal temperature at 15:00 as well as the lowest sweating rates at all three measurements compared to the Nelore and Angus x Nelore groups (Tables 1 and 2). 
Handling group $(\mathrm{HG})$ affected only sweating rate $(\mathrm{P}<0.01)$ and the interaction, $\mathrm{BT} x \mathrm{HG}$, did not affect any variable studied ( $P>0.05$ ). Time of taking the measurement (MED) and the interaction, HG $x$ MED, affected the sweating rate $(\mathrm{P}<0.01)$.

The ability and efficiency of the different breed types to maintain body temperature under basal levels are directly related to their thermoregulatory characteristics, that include coat length, density, thickness and colour, skin colour, sweat gland density and function, peripheral blood flow, respiratory cooling and heat production (Turner, 1984; Maia et al., 2003, Brown-Brandl et al., 2006). When an animal is outside its thermoneutral zone, it requires more energy to maintain body temperature, and thus less energy for production processes. Consequently, an animal modifies its behaviour, especially feeding, physiological and metabolic functions and the quantity and quality of its production are decreased. (Nardone et al., 2006)

\section{Conclusion}

Based on these results, Senepol x Nelore heifers showed a more efficient response during the heat tolerance test as compared to the Nelore and the Angus $x$ Nelore cross.

\section{References}

ASBIA, 2006. Relatório 2006 da Associação Brasileira de Inseminação Artificial, available from http:// www.asbia.org.br/mercado. (In Portuguese).

Brown-Brandl, T.M., Nienaber, J.A., Eigenberg, R.A., Mader, T.L., Morrow, J.L.F. \& Dailey, J.W., 2006. Comparison of heat tolerance of feedlot heifers of different breeds. Livest. Sci. 105, 19-26.

Buffington, D.E., Collazo-Arocho, A., Canton, G.H., Pitt, D., Thatcher, W.W. \& Collier, R.J., 1981 Black Globe Humidity-Index (BGHI) as comfort equation for dairy cows. Transactions of the ASAE. 24, 711-714.

FAS-USDA, 2008. Current World Production, Market and Trade Reports, available from http://www.fas.usda.gov/currwmt.asp.

Hahn, G.L. \& Mader, T.L., 1997. Heat waves in relation to thermoregulation, feeding behavior and mortality of feedlot cattle. In: Proc. $5^{\text {th }}$ Int. Livest. Environ. Symp., 1997, St Joseph. St. Joseph: Am. Soc. Agric. Eng.

Hansen, P.J., 2004. Physiological and cellular adaptations of zebu cattle to thermal stress. Anim. Reprod. Sci. 82-83, 349-360.

Maia, A.S.C., Silva, R.G. \& Bertipaglia, E., 2003. Características do pelame de vacas holandesa em ambiente tropical: um estudo genético e adaptativo. Rev. Bras. Zootec. 32, 843-853. (In Portuguese).

Nardone, A., Ronchi, B., Lacetera, N. \& Bernabucci, U., 2006. Climatic effects on productive traits in livestock. Vet. Res. Comm. 30, 75-81.

SAS, 2002. User’s Guide. versão 9.1.3, versão para Windows. Cary, N.C., USA, 2002-2003.

Thom, E.C., 1958. Cooling degree: day air conditioning, heating and ventilating, Trans. Am. Soc. Heat. Refr. Air-Cond. Engen. 55, 65-72,

Turner, H.G., 1984. Variation in rectal temperature of cattle in a tropical environment and its relation to growth rate. Anim. Prod. 38, 417-427. 